\title{
EDIBLE COATING BERBASIS PATI SAGU DENGAN PENAMBAHAN ANTIMIKROBA MINYAK SEREH PADA PAPRIKA: PREFERENSI KONSUMEN DAN MUTU VITAMIN C
}

\author{
Edible Coating Based on Sago Starch with Antimicrobe Addition of Lemongrass Oil on Red Bell Pepper: \\ Consumer's Acceptability and Quality of Vitamin C
}

Widaningrum, Miskiyah, Christina Winarti

Balai Besar Penelitian dan Pengembangan Pascapanen Pertanian, Jl. Tentara Pelajar No.12A, Bogor 16114

Email: widaningrum.adnan@gmail.com; widaningrum_adnan@yahoo.com

\begin{abstract}
ABSTRAK
Paprika merupakan salah satu jenis sayuran buah yang memiliki prospek pasar yang cerah dan terbuka lebar baik untuk pasar domestik maupun ekspor. Namun, paprika merupakan sayuran buah yang tidak awet dan mudah rusak (perishable commodity) sehingga paprika memerlukan penanganan pascapanen yang tepat agar dapat meningkatkan masa simpannya. Salah satu teknologi potensial untuk diterapkan pada paprika yaitu pelapisan permukaan paprika dengan bahan edible (dapat dimakan) dan ditambah dengan antimikroba alami untuk menghindari serangan mikroba. Penelitian ini bertujuan untuk mengetahui pengaruh konsentrasi minyak sereh dan lama perendaman terhadap sifat kimia dan organoleptik (warna, aroma, tekstur dan rasa) paprika merah yang diberi perlakuan edible coating berbasis pati sagu dan antimikroba alami minyak sereh. Selain itu juga dianalisis perubahan mutu kimia vitamin $\mathrm{C}$ pada paprika merah selama penyimpanan. Perlakuan yang diberikan untuk pengujian karakteristik sensori yaitu (a) konsentrasi minyak sereh $0,2 \%$ dan $0,4 \%$ dan (b) lama pencelupan dalam formula edible coating yaitu 3 dan 5 menit. Paprika lalu disimpan pada suhu $8^{\circ} \mathrm{C}$. Sebagai kontrol dilakukan juga pengamatan terhadap paprika yang tidak di coating dan yang di coating namun tanpa menambahkan minyak sereh. Hasil penelitian menunjukkan bahwa perlakuan coating tidak berpengaruh nyata pada penerimaan panelis terhadap atribut aroma, tekstur, rasa maupun penerimaan keseluruhan paprika. Perlakuan coating hanya berpengaruh nyata pada penerimaan panelis terhadap atribut warna paprika merah. Panelis dapat menerima perlakuan coating pada paprika, baik dengan atau tanpa penambahan antimikroba. Kandungan vitamin $\mathrm{C}$ pada paprika dengan perlakuan $0,4 \%$ minyak sereh pada suhu $8^{\circ} \mathrm{C}$ pada hari penyimpanan ke- 27 masih tetap tinggi yaitu $1,5 \mathrm{mg} / 100 \mathrm{~g}$.
\end{abstract}

Kata kunci: Paprika, edible coating, preferensi konsumen, vitamin $\mathrm{C}$

\begin{abstract}
Bell pepper is one among fruit vegetables that had good market prospect both for local trade and export. Nevertheless, the commodity has perishable properties thus it needs good post harvest handling that could increase its shelf life. One of among other technologies, surface coating (by edible coating) of bell pepper is potential to be applied. This technology might be added by natural antimicrobes to avoid microorganism attack during storage time, so its shelf life might be extended. The objective of this research was to evaluate consumer's acceptability and vitamin $\mathrm{C}$ content on red bell pepper which were applied by edible coating based on sago starch and lemongrass oil that acting as natural antimicrobes. Treatment given for testing its sensory properties were: (a) concentration of lemongrass oil $(0.2 \%$ and $0.4 \%)$ and (b) dipping time in edible coating formula; 3 and 5 minutes. Red bell pepper wasthen stored at cold room temperature $\left(8{ }^{\circ} \mathrm{C}\right)$. As control treatment, the inspection was also applied on non-coated red bell pepper and coated red bell pepper without addition of lemongrass oil. Result showed that coating treatment did not affect consumer's acceptability on aroma, texture, taste and overall acceptability. Coating treatment only affected consumer's acceptability on color of red bell pepper. Panelists could accept coating treatment on red bell pepper with or without addition of lemongrass oil as antimicrobes. Moreover, red bell pepper treated by $0.4 \%$ lemongrass oil storaged at $8^{\circ} \mathrm{C}$ was still had high vitamin $\mathrm{C}$ content $(1.5 \mathrm{mg} / 100 \mathrm{~g})$ on 27 days storage.
\end{abstract}

Keywords: Red bell pepper, edible coating, consumer's acceptability, vitamin C 


\section{PENDAHULUAN}

Paprika (Capsicum annuum var. Athena) merupakan salah satu sayuran yang memiliki prospek yang cerah. Peluang pasar luar dan dalam negeri masih terbuka luas. Hal ini sejalan dengan pertumbuhan pasar swalayan di dalam negeri dan banyaknya permintaan dari eksportir untuk ekspor ke luar negeri. Sayuran buah ini mempunyai pangsa pasar tertentu, antara lain hotel, restoran, katering, dan pasar swalayan. Produksi paprika 60-80 ton lebih per bulan (Anonymous, 2014) belum mampu memenuhi permintaan dalam dan luar negeri. Untuk pasar luar negeri, ekspor paprika Indonesia telah mencapai beberapa negara seperti Taiwan dan Singapura. Sebagai contoh, permintaan paprika dari Singapura mencapai 20-30 ton per minggu. Harga jual paprika pun cenderung lebih tinggi daripada cabai biasa, kira-kira tiga sampai lima kali harga cabai biasa (Yusniwati dkk., 2004). Oleh karena itu paprika merupakan sayuran yang memiliki nilai ekonomi yang sangat tinggi.

Kendala utama ekspor hortikultura termasuk paprika adalah sifat produk yang mudah rusak dan pertumbuhan mikroorganisme yang merupakan penyebab utama kebusukan pangan segar. Beberapa kasus kontaminasi mikroba pada bahan makanan segar seringkali menyebabkan efek yang serius terhadap kesehatan manusia. Paprika tergolong sebagai jenis sayuran yang mudah rusak (perishable commodity), mempunyai daya simpan antara 1-2 minggu (Kader 1992). Permasalahan yang umum terjadi pada pascapanen paprika antara ian (a) busuk dan perubahan tekstur (Miller dkk.,1983), (b) kisut akibat hilangnya air (Miller dkk., 1983, Lerdthanangkul dan Krochta, 1996), (c) meningkatnya jumlah bakteri penyebab tangkai lunak, dan (d) suhu rendah selama penyimpanan yang menyebabkan terjadinya chilling injury dan meningkatnya kapang Alternaria (Miller dkk.,1983). Oleh karena itu, diperlukan upaya-upaya untuk mengatasi hal tersebut.

Teknologi edible coating merupakan teknologi yang dipertimbangkan sebagai salah satu pendekatan untuk meningkatkan masa simpan produk pertanian segar, termasuk paprika. Edible coating dapat berasal dari bahan baku yang mudah diperbaharui seperti campuran lipid, polisakarida, dan protein, yang berfungsi sebagai barrier uap air, gas, dan zatzat terlarut lain serta berfungsi sebagai carrier (pembawa) berbagai macam ingridien seperti emulsifier, antimikroba dan antioksidan, sehingga berpotensi untuk meningkatkan mutu dan memperpanjang masa simpan buah-buahan dan sayuran segar terolah minimal (Lin dan Zhao, 2007).

Beberapa keuntungan produk yang dikemas dengan edible coating berbasis pati antara lain (a) menurunkan aktivitas air pada permukaan bahan sehingga kerusakan oleh mikroorganisme dapat dihindari karena terlindung oleh lapisan ediblefilm, (b) memperbaiki struktur permukaan bahan sehingga permukaan menjadi mengkilat, (c) mengurangi terjadinya dehidrasi sehingga susut bobot dapat dicegah, (d) mengurangi kontak oksigen dengan bahan sehingga oksidasi atau ketengikan dapat dihambat, (e) sifat asli produk seperti flavor tidak mengalami perubahan, dan (f) memperbaiki penampilan produk (Santoso dkk.,2004). Aplikasi edible coating berbasis pati telah dilakukan untuk mempertahankan tingkat kesegaran pada irisan mangga (Baldwin dkk., 1996) dan lempok (Harris, 2001), namun data pada paprika merah belum tersedia. Hasil uji sensoris yang dilakukan oleh Robson dkk. (2008) menunjukkan bahwa coating menggunakan pati ubi kayu selama penyimpanan bawang putih menunjukkan tingkat penerimaan yang bagus dari semua atribut sensori yang diuji.

Data aplikasi edible coating pada produk sayuran di Indonesia masih terbatas, termasuk diantaranya data preferensi konsumen dan mutu kimia vitamin $\mathrm{C}$ setelah pelapisan dilakukan. Penambahan antimikroba perlu dilakukan untuk melindungi produk yang dilapisi coating agar terhindar dari serangan mikroba sehingga dapat memperpanjang masa simpan produk. Aplikasi edible coating diduga tidak memengaruhi mutu sensoris dan mutu mikrobiologi paprika merah.

Teknologi edible coating merupakan teknologi yang dipertimbangkan sebagai salah satu pendekatan atau solusi bagaimana cara meningkatkan masa simpan dan keamanan mikrobiologis produk-produk segar. Edible coating dapat berasal dari bahan baku yang mudah diperbaharui seperti campuran lipid, polisakarida, dan protein, yang berfungsi sebagai barrier uap air, gas, dan zat-zat terlarut lain serta berfungsi sebagai carrier (pembawa) berbagai macam ingridien seperti emulsifier, antimikroba dan antioksidan, sehingga berpotensi untuk meningkatkan mutu dan memperpanjang masa simpan buah-buahan dan sayuran segar terolah minimal (Lin dan Zhao, 2007).

Tujuan penelitian ini adalah untuk mengetahui pengaruh konsentrasi minyak sereh dan lama perendaman terhadap sifat kimia dan organoleptik (warna, aroma, tekstur dan rasa) paprika merah yang diberi perlakuan edible coating berbasis pati sagu dan antimikroba alami minyak sereh. Selain itu juga dianalisis perubahan mutu kimia vitamin $\mathrm{C}$ pada paprika merah selama penyimpanan.

\section{METODE PENELITIAN}

Penelitian dilakukan di Laboratorium Balai Besar Penelitian dan Pengembangan Pascapanen Pertanian Bogor, pada bulan Maret sampai Oktober 2009. Bahan yang digunakan yaitu paprika merah (Capsicum annuum var. Athena), pati sagu, gliserol, carboxymethyl cellulose (CMC), minyak biji 
bunga matahari (sunflower oil), minyak sereh 0.2 dan $0.4 \%$, etanol 95\%, akuades, dan bahan-bahan untuk analisis vitamin C. Alat-alat yang digunakan yaitu panci, kain kasa, penangas, pengaduk, plastic wrap, boks styrofoam, oven vakum, neraca analitik, hand mixer merk Philips, kain saring, gelas piala, hot plate, kantong plastik berkelim, cawan porselin, iod $0.01 \mathrm{~N}$, erlenmeyer, dan lain-lain peralatan untuk analisis.

\section{Pembuatan Larutan Edible Film Berbasis Pati Sagu}

Proses pembuatan ediblecoating berbasis pati sagu dilakukansebagai berikut:sebanyak 1 bagian pati sagu dari persiapan pati sagu dicampur dengan 10 bagian akuades dan diaduk dengan mixer skala 1 sampai homogen selama 10 menit, lalu disaring dengan kain saring. Suspensi pati dimasukkan ke dalam gelas piala $1000 \mathrm{ml}$ dan dipanaskan di atas hot plate sambil diaduk dengan hand mixer skala 1 sampai mencapai suhu $\pm 65^{\circ} \mathrm{C}$, kemudian ditambahkan karboksimetilselulosa (CMC 1,0\%) sedikit demi sedikit sambil terus dipanaskan dan diaduk dengan mixer skala 2 sampai homogen. Setelah itu, campuran ditambahkan gliserol (10\%) sedikit demi sedikit sambil terus dipanaskan dan diaduk dengan mixer skala 1, sampai suspensi pati mengental (yang dicapai pada suhu $\pm 72^{\circ} \mathrm{C}$ dalam waktu \pm 10 menit). Selanjutnya larutan ditambahkan minyak bunga matahari sebanyak 0,025\% sebagai plastisizer. Larutan kemudian didinginkan hingga suhu $30^{\circ} \mathrm{C}$, selanjutnya dilakukan penambahan minyak sereh $(0,2$; dan $0,4 \%)$ sebelum diaplikasikan pada paprika.

\section{Aplikasi Edible Coating pada Paprika Merah}

Paprika merah (Capsicum annum var. Athena) yang memiliki umur panen yang seragam dengan tangkainya dicuci bersih, kemudian ditiriskan dan diberi perlakuan pelapisan edible coating dengan cara pencelupan dalam formula edible coating. Paprika dicelupkan pada larutan edible coating selama 3 dan 5 menit, selanjutnya paprika tersebut dikeringanginkan. Pengemasan dilakukan dengan meletakkan paprika ke dalam box styrofoam satu per satu dan ditutup plastic wrap, selanjutnya paprika disusun pada rak-rak dan disimpan pada suhu penyimpanan cold room $\left(8^{\circ} \mathrm{C}\right)$ sampai paprika menjadi rusak. Penyimpanan dilakukan tanpa memperhatikan faktor pencahayaan pada ruang penyimpanan. Parameter kerusakan pada paprika yang dimaksud yaitu kisut, adanya kapang, dan lepasnya bagian batang. Jika ditemukan salah satu dari parameter tersebut, sampel paprika dinyatakan rusak. Paprika yang telah diberi perlakuan edible coating lalu dianalisis kandungan vitamin $\mathrm{C}$-nya.

\section{Uji Sensori}

Pengujian sensori dilakukan untuk mengetahui pengaruh coating terhadap tingkat penerimaan panelis. Uji sensori dilakukan dengan uji rating hedonik, berdasarkan metode Meilgaard dkk.(1999). Panelis diminta untuk memberi penilaian berdasarkan kesukaannya. Parameter uji meliputi tekstur, warna, aroma, rasa dan penerimaan umum. Uji ini dilakukan 1 hari setelah perlakuan coating. Uji rating hedonik menggunakan skala 1-7, dimana kriteria penilaiannya adalah (1) sangat tidak suka, (2) tidak suka, (3) agak tidak suka, (4) netral, (5) agak suka, (6) suka, dan (7) sangat suka, terhadap parameter uji yang sudah ditentukan. Uji sensori dilaksanakan dengan menggunakan 35 orang panelis tidak terlatih yang berasal dari lingkungan Balai Besar Penelitian dan Pengembangan Pascapanen Pertanian, Bogor.

\section{Vitamin C}

Kandungan vitamin $\mathrm{C}$ ditentukan dengan cara titrasi iod (AOAC, 1999). Sebanyak 30 gram sampel dilarutkan dengan aquades dalam labu takar $100 \mathrm{ml}$ kemudian disaring. Diambil sebanyak $10 \mathrm{ml}$ larutan sampel, ditetesi indikator pati 4-5 tetes, dan dititrasi menggunakan larutan iod $0.01 \mathrm{~N}$. Titik akhir titrasi ditandai dengan perubahan warna larutan menjadi biru. Kadar Vitamin $\mathrm{C}$ dihitung dengan rumus :

Vitamin $\mathrm{C}(\mathrm{mg} / 100$ gram bahan $)=\frac{\mathrm{V} \times \mathrm{N} \times 0.88 \times \mathrm{FP} \times 100 \%}{0,01 \times \mathrm{W}}$

$\mathrm{V}=$ Volume iod yang digunakan $(\mathrm{ml})$

$\mathrm{N}=$ Normalitas iod hasil standarisasi

$\mathrm{FP}=$ Faktor pengenceran

$\mathrm{W}=$ Berat sampel (gram)

\section{Analisis Statistik}

Untuk data uji sensori, rancangan penelitian yang digunakan yaitu rancangan acak lengkap faktorial terdiri dari 2 faktor, yaitu faktor A (konsentrasi minyak sereh, A1:0,2\%; dan A2:0,4\%) dan faktor B (lama pencelupan, B1:3 menit dan B2:5 menit). Paprika yang diujikan adalah paprika merah yang disimpan pada suhu $8^{\circ} \mathrm{C}$ pada hari ke-0 penyimpanan. Kontrol perlakuan adalah paprika tanpa coating dan dicoating tetapi tanpa ditambahkan minyak sereh. Analisis ragam (ANOVA) diterapkan pada data yang diperoleh dan dilanjutkan dengan uji beda rata-rata (Duncan Multiple Range Test) untuk mengetahui adanya pengaruh perlakuan terhadap karakteristik atribut sensori dan vitamin C paprika merah. Analisis statistik dilakukan dengan menggunakan software SPSS 15.0.

\section{HASIL DAN PEMBAHASAN}

\section{Karakteristik Sensori}

Uji sensori bertujuan untuk mengetahui tingkat kesukaan panelis terhadap paprika. Selain itu, uji sensori bertujuan untuk 
mengetahui apakah ada perbedaan yang nyata antara paprika tidak dicoating, paprika dicoating tanpa penambahan minyak sereh, serta paprika dicoating dengan penambahan minyak sereh terhadap penerimaan sensori panelis. Hal tersebut perlu dilakukan karena ediblecoating yang dikehendaki adalah edible coating yang tidak berasa, tidak berbau, dan tidak menyebabkan adanya perubahan sensori. Uji organoletik yang digunakan adalah uji rating hedonik. Uji dilakukan satu hari setelah coating.

\section{Warna}

Warna merupakan kriteria penting penerimaan konsumen terhadap suatu produk. Histogram penilaian panelis pada atribut warna ditampilkan pada Gambar 1. Hasil uji anova menunjukkan bahwa pada taraf signifikansi 0,05 , perlakuan coating baik tanpa maupun dengan minyak sereh berpengaruh sangat nyata $(\mathrm{P}<0,01)$ terhadap penerimaan warna antar sampel paprika merah.

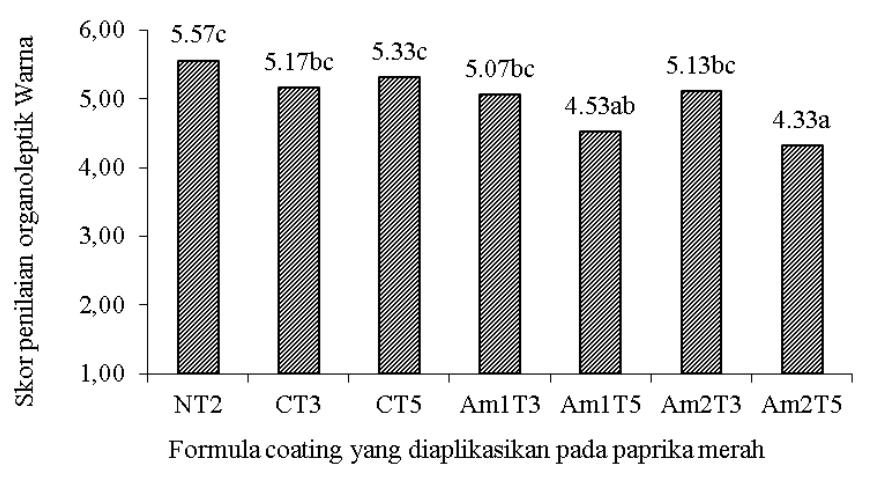

Gambar 1. Nilai rata-rata skor penilaian organoleptik panelis terhadap warna paprika merah

Analisis penerimaan warna menunjukkan bahwa panelis paling menyukai paprika merah yang tidak dicoating (NT2), dengan rerata skor kesukaan 5,57 ("agak suka sampai suka") dan hal ini tidak berbeda nyata dengan skor paprika merah yang dicoating tetapi tanpa ditambah minyak sereh, baik dicelup selama 3 menit (CT3) maupun 5 menit (CT5), dengan rerata skor kesukaan 5,17 dan 5,33. Untuk paprika yang dicelup minyak sereh $0,2 \%$ baik selama 3 menit (Am1T3) maupun 5 menit (Am1T5), panelis memberi nilai berbeda dimana skor nilai Am1T3 lebih tinggi $(5,07)$ atau "agak suka" daripada Am1T5 (4,53) atau "netra;", sebanding dengan nilai yang dimiliki oleh sampel paprika yang dicelup minyak sereh 0,4\% selama 3 menit (Am2T3), yaitu 5,13 ("agak suka”). Dalam hal warna, panelis lebih menyukai sampel paprika merah yang dicoating formula dengan konsentrasi minyak sereh $0,4 \%$ selama 3 menit. Hal ini dapat dilihat dari nilai yang paling kecil yang dimiliki oleh sampel paprika yang dicoating dengan minyak sereh $0,4 \%$ selama 5 menit (Am2T5) yaitu
4,33. Panelis lebih menyukai paprika merah tanpa dicoating karena warna yang dipancarkan lebih alami dibandingkan paprika merah yang dicoating. Demikian pula coating yang lebih lama (5 menit) menyebabkan penampakan warna paprika merah lebih mengkilat dan tampak tebal (Gambar 2) sehingga paprika merah yang lebih sebentar dicoating dan yang tanpa dicoating lebih disukai panelis.

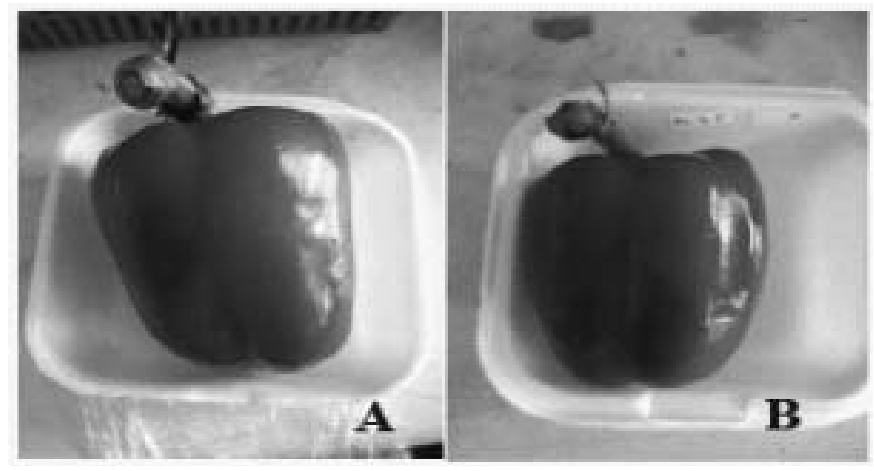

Gambar 2. Perbandingan warna papria merah yang tidak dicoating (A) dan yang dicoating $(\mathrm{B})$

Tiga aspek penting dalam penerimaan makanan ialah warna, rasa, dan tekstur. Warna merupakan faktor terpenting dalam hal penerimaan, karena jika produk terlihat tidak menarik, maka konsumen akan menolak produk tersebut tanpa memperhatikan faktor lainnya (Nielsen, 2003). Warna paprika terutama berasal dari sintesis karotenoid yang terbentuk selama proses pematangan buah.Sintesis karotenoid dipicu oleh meningkatnya konsentrasi $\mathrm{O}_{2}$, etilen, dan meningkatnya suhu penyimpanan (Harris, 2001).

\section{Aroma}

Paprika memiliki aroma yang khas, yaitu pedas menusuk seperti cabai. Adanya perlakuan coating diharapkan tidak mengubah aroma khas tersebut. Hasil uji anova menunjukkan bahwa perlakuan coating baik tanpa maupun dengan minyak sereh tidak berpengaruh nyata $(\mathrm{P}>0,05)$ terhadap penerimaan aroma pada taraf signifikansi 0,05 . Khusus untuk aroma, setiap sampel diterima dengan kesukaan yang seragam oleh panelis, yaitu "netral" dengan rerata skor aroma 4,20-4,63 (Gambar 3).

Dalam hal ini, meskipun coating dapat berperan sebagai barrier yang cukup baik sehingga dapat mereduksi hilangnya komponen volatil (Olivas dkk.,2007), namun panelis masih dapat menerima perbedaan aroma akibat perlakuan pelapisan (coating) ini. Bahan baku edible coating yang berupa pati sagu dengan gliserol dan CMC tidak mengeluarkan aroma yang menusuk sehingga panelis masih dapat menerima perbedaan perlakuan yang dicobakan. Selain itu minyak biji bunga matahari (sunflower oil) dan minyak sereh yang ditambahkan 


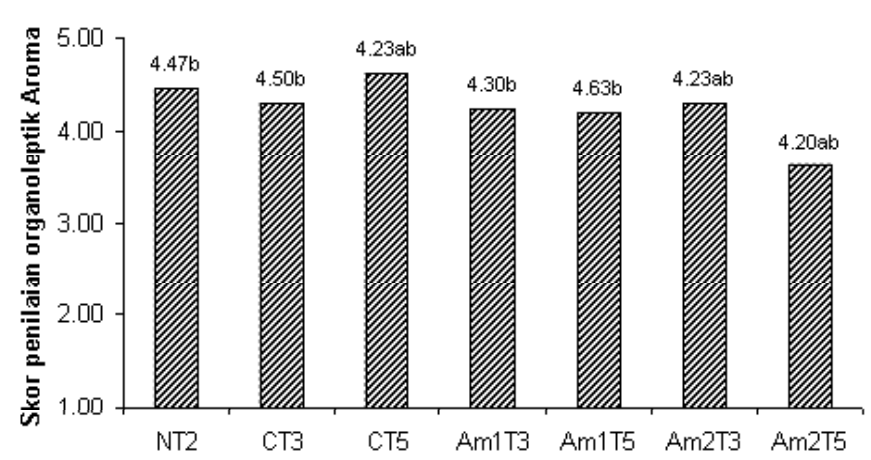

Formula coating yang diaplikasikan pada paprika merah

Ket : NT2 = tidak dicoating,

CT3 = coating tanpa minyak sereh-celup 3 menit,

CT5 = coating tanpa minyak sereh-celup 5 menit,

AM1T3 = minyak sereh $0.2 \%$, celup 3 menit,

AM1 T5 = minyak sereh $0.2 \%$, celup 5 menit,

AM2T3 = minyak sereh $0.4 \%$, celup 3 menit,

AM2 T5 = minyak sereh $0.4 \%$, celup 5 menit.

huruf yang berbeda menyatakan sampel berbeda nyata pada taraf signifikansi 0.05

Gambar 3. Nilai rata-rata skor penilaian organoleptik panelis terhadap aroma paprika merah

konsentrasinya cukup minimal yaitu masing-masing $0,025 \%$; 0,2 dan $0,4 \%$ sehingga tidak mengeluarkan aroma yang menyengat dan diterima tidak berbeda oleh panelis.

\section{Tekstur}

Tekstur merupakan salah satu atribut mutu dari suatu produk. Hasil uji anova menunjukkan bahwa perlakuan coating baik tanpa maupun dengan minyak sereh berpengaruh nyata

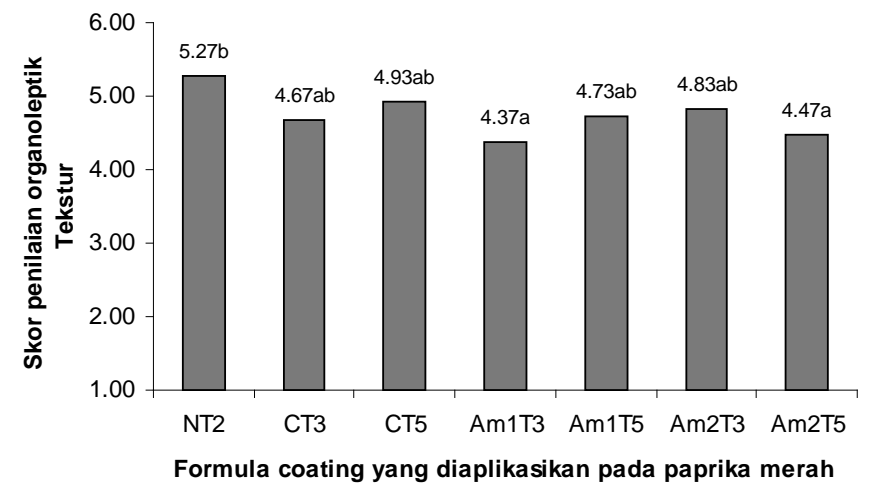

Ket : NT2 $=$ tidak dicoating,

CT3 = coating tanpa minyak sereh-celup 3 menit,

CT5 = coating tanpa minyak sereh-celup 5 menit,

AM1T3 = minyak sereh $0.2 \%$, celup 3 menit,

AM1T5 = minyak sereh $0.2 \%$, celup 5 menit,

AM2T3 = minyak sereh $0.4 \%$, celup 3 menit,

AM2 T5 = minyak sereh $0.4 \%$, celup 5 menit,

huruf yang berbeda menyatakan sampel berbeda nyata pada taraf signifikansi 0.05

Gambar 4. Nilai rata-rata skor penilaian organoleptik panelis terhadap tekstur paprika merah
$(\mathrm{P}<0,05)$ terhadap penerimaan tekstur pada taraf signifikansi 0,05 (Gambar 4). Panelis memberi nilai antara "netral" sampai "agak suka" dengan nilai rerata skor 4,37-5,27. Untuk sampel yang diberi perlakuan coating dengan tambahan minyak sereh, panelis paling menyukai paprika dengan konsentrasi minyak sereh 0,4\% dengan dicelup 3 menit (Am2T3) dengan skor kesukaan 4,83 ("agak suka"), namun hal ini tidak berbeda dengan Am1T5 dengan skor kesukaan 4,73 (“agak suka”).

Hasil penelitian menunjukkan bahwa kombinasi perlakuan coating dengan kombinasi suhu penyimpanan efektif mempertahankan kekerasan paprika merah (Miskiyah dkk., 2010). Penyimpanan pada suhu rendah dapat mencegah pelunakan tekstur karena dapat menurunkan laju respirasi dan transpirasi, menghambat enzim hidrolitik dinding sel, dan menurunkan laju etilen (Sethu dkk. 1996). Pelapisan dengan edible coating mampu menghambat laju respirasi dan menekan terjadinya pelunakan (Vina dkk., 2007).

\section{Rasa}

Rasa merupakan kriteria penting penerimaan konsumen terhadap suatu produk. Hasil uji anova menunjukkan bahwa perlakuan coating baik tanpa maupun dengan minyak sereh tidak berpengaruh nyata $(\mathrm{P}>0.05)$ terhadap penerimaan rasa paprika merah pada taraf signifikansi 0,05 (Gambar 5). Sampel yang tidak diberi perlakuan coating atau coating tanpa minyak sereh memiliki nilai rerata skor kesukaan yang tertinggi tetapi tidak berbeda nyata dengan sampel lainnya. Sampel-sampel yang dicoating masih dapat diterima dengan skor kesukaan "netral" dengan nilai rerata skor 4,07-4,70.

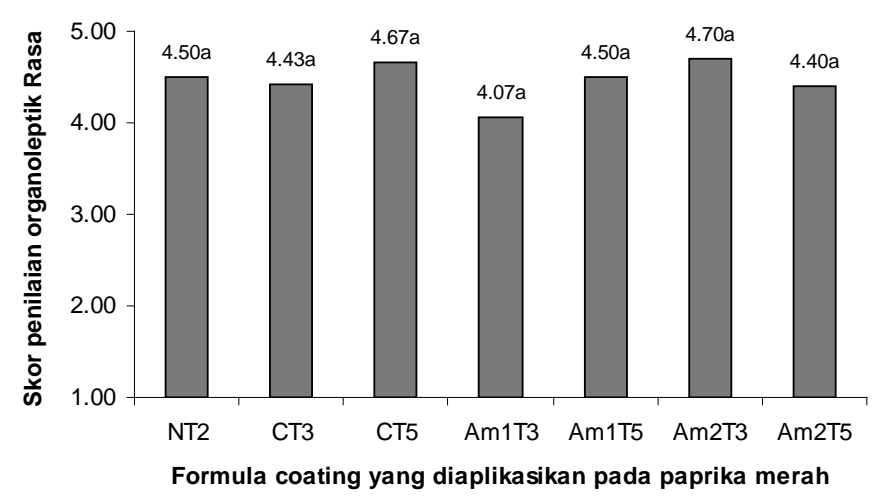

Ket : NT2 = tidak dicoating,

CT3 = coating tanpa minyak sereh-celup 3 menit,

CT5 = coating tanpa minyak sereh-celup 5 menit,

AM1T3 = minyak sereh $0.2 \%$, celup 3 menit,

AM1T5 = minyak sereh $0.2 \%$, celup 5 menit,

AM2T3 = minyak sereh $0.4 \%$, celup 3 menit,AM2 T5 = minyak sereh $0.4 \%$, celup 5 menit

Gambar 5. Nilai rata-rata skor penilaian organoleptik panelis terhadap rasa paprika merah 


\section{Penerimaan Umum}

Uji sensori keseluruhan bertujuan untuk melihat penerimaan panelis. Hasil uji anova menunjukkan bahwa perlakuan coating baik tanpa maupun dengan minyak sereh tidak berpengaruh nyata $(\mathrm{P}>0,05)$ terhadap penerimaan keseluruhan paprika merah pada taraf signifikansi 0,05 (Gambar 6). Walaupun setiap perlakuan tidak berbeda nyata, paprika merah yang paling disukai oleh panelis adalah paprika merah tanpa dicoating. Konsentrasi minyak sereh $0,4 \%$ dan pencelupan 3 menit tetap dinilai tidak berbeda nyata dengan semua sampel lain yang diberi perlakuan coating dan ditambah minyak sereh, kecuali perlakuan minyak sereh $0.4 \%$ dan pencelupan 5 menit memiliki rerata skor kesukaan terendah.

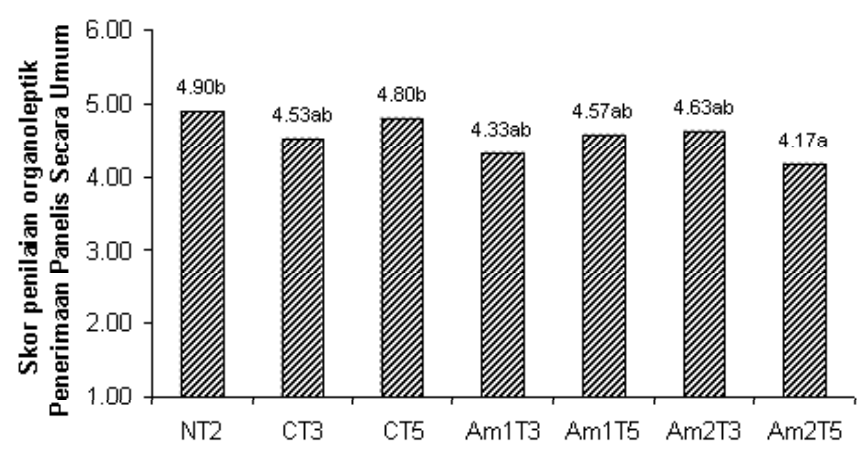

Formula coating yang diaplikasikan pada paprika merah

Ket : NT2 = tidak dicoating,

CT3 = coating tanpa minyak sereh-celup 3 menit,

CT5 = coating tanpa minyak sereh-celup 5 menit,

AM1T3 = minyak sereh $0.2 \%$, celup 3 menit,

AM1T5 = minyak sereh $0.2 \%$, celup 5 menit,

AM2T3 = minyak sereh $0.4 \%$, celup 3 menit,

AM2 T5 = minyak sereh $0.4 \%$, celup 5 menit,

huruf yang berbeda menyatakan sampel berbeda nyata pada taraf signifikansi 0.05

Gambar 6. Nilai rata-rata skor penilaian organoleptik panelis terhadap penerimaan umum paprika merah

\section{Vitamin C}

Kadar vitamin C selama penyimpanan cenderung menurun. Penurunan kadar vitamin $\mathrm{C}$ selama penyimpanan terutama disebabkan kondisi suhu ruang penyimpanan yang tidak sesuai, yaitu disimpan pada suhu rendah. Perubahan kadar vitamin C juga disebabkan terjadinya oksidasi L-ascorbic acid menjadi L-dehydroascorbic. Kerusakan dinding sel dan proses buah menjadi lewat masak (overripenes) juga mempengaruhi penurunan kadar vitamin C (Wojdyla dkk., 2008). Dari Gambar 7 sampai dengan Gambar 10 terlihat bahwa pada suhu penyimpanan $8^{\circ} \mathrm{C}$, walaupun terjadi penurunan kadar vitamin $\mathrm{C}$, tingkat penurunannya cenderung rendah. Hal ini disebabkan suhu penyimpanan yang rendah akan menghambat proses metabolisme sehingga penurunan kadar vitamin $\mathrm{C}$ juga lebih rendah.

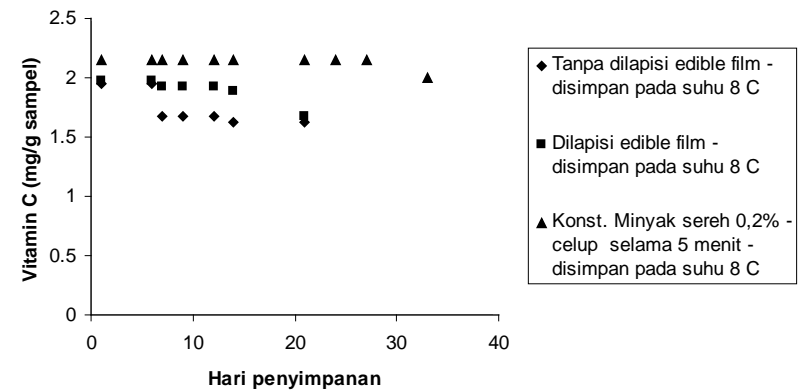

Gambar 7. Perubahan kadar vitamin C paprika merah yang telah di-coating dengan pencelupan selama 3 menit di dalam formula coating yang ditambah minyak sereh $0.2 \%$ selama penyimpanan

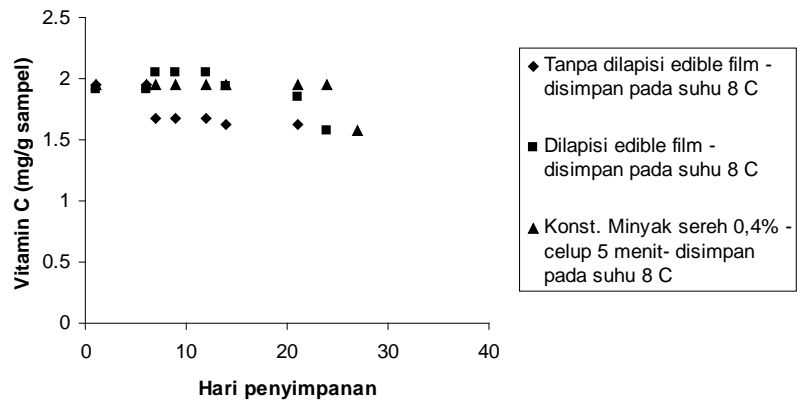

Gambar 8. Perubahan kadar Vitamin C paprika merah yang telah di-coating dengan pencelupan selama 5 menit di dalam formula coating yang ditambah minyak sereh $0.2 \%$ selama penyimpanan

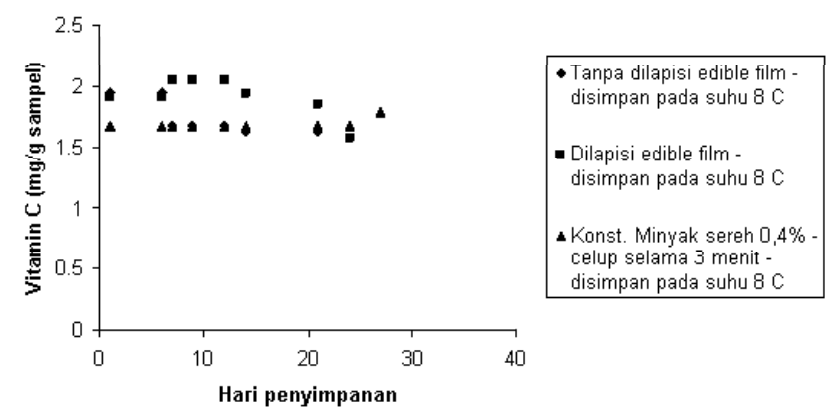

Gambar 9. Perubahan kadar vitamin $\mathrm{C}$ paprika merah yang telah di-coating dengan pencelupan selama 3 menit di dalam formula coating yang ditambah minyak sereh $0.4 \%$ selama penyimpanan

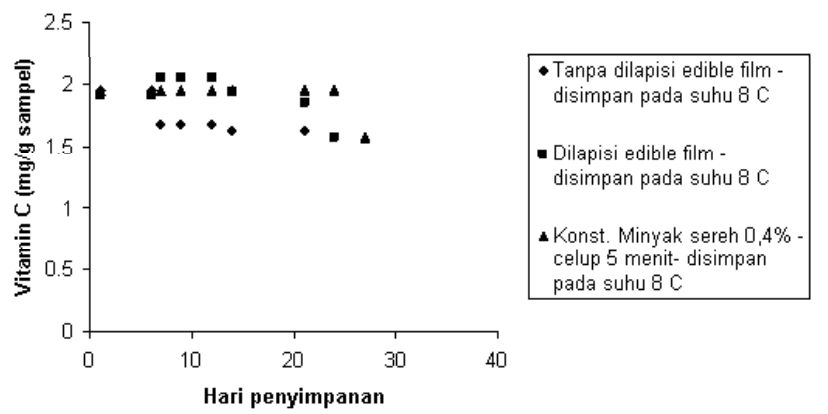

Gambar 10. Perubahan kadar vitamin C paprika merah yang telah di-coating dengan pencelupan selama 5 menit di dalam formula coating yang ditambah minyak sereh $0.4 \%$ selama penyimpanan 
Secara umum, pada semua perlakuan konsentrasi minyak sereh yang dicobakan $(0,2 \%$ dan $0,4 \%)$ serta lama pencelupan pada larutan formula edible film terpilih (3 dan 5 menit), kadar vitamin $\mathrm{C}$ pada paprika merah kontrol menunjukkan nilai yang relatif stabil, sama dengan yang disimpan pada suhu $8^{\circ} \mathrm{C}$ (Gambar 6-9). Pada kontrol dan semua perlakuan, paprika merah sudah mengalami kerusakan setelah hari ke27 atau hari ke-33 penyimpanan.

Analisis ragam menunjukkan bahwa faktor tunggal lama pencelupan dalam formula edible coating yang masingmasing berpengaruh nyata $(\mathrm{P}<0,05)$ terhadap kadar vitamin $\mathrm{C}$ paprika merah sedangkan interaksi perlakuan kedua faktor tersebut (lama pencelupan dan konsentrasi minyak sereh) tidak berpengaruh nyata $(\mathrm{P}>0,05)$. Dari hasil penelitian ini, dapat ditarik kesimpulan bahwa perlakuan yang efektif untuk melapisi paprika merah adalah coating dengan penambahan minyak sereh 0,4\%-pencelupan selama 5 menit dan disimpan pada suhu $8^{\circ} \mathrm{C}$. Pada perlakuan tersebut, kadar vitamin $\mathrm{C}$ pada paprika merah masih tinggi yaitu $1,5 \mathrm{mg} / 100 \mathrm{~g}$.

Hasil penelitian Ayranci dan Tunc (2004) yang membuat edible coating dari methyl cellulose (MC) dan polyethylene glycol (PEG) pada peningkatan umur simpan paprika hijau menunjukkan bahwa penambahan asam stearat (SA) sebagai antioksidan pada formula edible coating paling efektif dalam mengurangi kehilangan air paprika hijau. Penambahan asam askorbat (AA) atau asam sitrat (AS) mengurangi penurunan kadar Vitamin C paprika hijau.

Dalam penelitian tersebut, edible coating MC-PEGSAdapat menurunkan susut bobot (kehilangan air) paprika hijau pada akhir hari penyimpanan ke-10. Perlakuan tersebut juga mempengaruhi kadar Vitamin $\mathrm{C}$ pada akhir hari penyimpanan ke-20. Hal ini disebabkan karena asam stearat mampu menciptakan kondisi hidrofobik pada permukaan paprika hijau sehingga mengurangi kehilangan air dan mencegah susut bobot yang lebih banyak serta mempertahankan kadar Vitamin C. Asam stearat sebagai aditif (antioksidan) pada formula coating memiliki efek yang lebih baik dalam mengurangi kehilangan Vitamin C. Namun menurut Ayranci dan Tunc (2004), efek paling utama berasal dari gabungan aditif asam sitrat, asam askorbat dan antioksidan asam stearat.

\section{KESIMPULAN}

Hasil uji sensori pada produk paprika merah yang telah diberiperlakuanediblecoatingmenunjukkanperlakuancoating tidak berpengaruh nyata pada penerimaan panelis terhadap atribut warna, aroma, tekstur, rasa, dan penerimaan umum paprika. Penerimaan panelis terhadap paprika yang dicoating baik dengan maupun tanpa penambahan minyak sereh berada dalam kisaran netral, yaitu masih dapat diterima. Walaupun aplikasi coating pada paprika tidak mampu menurunkan laju kerusakan dari sifat fisik dan sifat kimia, tetapi mampu memperpanjang umur simpan paprika. Perlakuan coating pada suhu coldroom mampu memperpanjang umur simpan paprika selama 3-7 hari. Kombinasi perlakuan coating dengan penambahan minyak sereh efektif dalam memperpanjang umur simpan paprika. Perubahan kadar vitamin C pada paprika merah hanya dipengaruhi oleh faktor tunggal lama pencelupan dalam formula edible coating.

\section{DAFTAR PUSTAKA}

AOAC. Association of Official Analytical Chemistry (1999). Official Methods of Analysis. Washington DC: AOAC Int.http://www.aoac.org/vmeth/page1.htm. [26 Desember 2011].

Anonymous (2014). Ekspor paprika: permintaan tembus 40 ton per minggu. http://bandung.bisnis. $\mathrm{com} / \mathrm{m} / \mathrm{read} / 20130828 / 5 / 421228 /$ ekspor-paprikapermintaantembus-40-ton-per-minggu. $\quad[14$ April 2014].

Ayranci, E. dan Tunc, D.S. (2004). The effect of edible coating on water and vitamin C loss of apricot (Armeniaca vulgaris Lam.) and green peppers (Capsicum annum L.). Food Chemistry 87: 339-342.

Baldwin, E.A., Nisperos, M.O., Chen, X. dan Choi, W.Y. (2003). Extending storage-life of minimally processed apples with edible coatings and antibrowning agents. Lebensmittel-Wissenschaft und -Technologie 36: 323329.

Harris, H. (2001). Kemungkinan penggunaan edible film dari pati tapioka untuk pengemas lempuk. Jurnal Ilmu-ilmu Pertanian Indonesia 3(2): 99-106.

Kader, A.A. (1992). Postharvest Technology of Horticultural Crops. University of California, California.

Lerdthanangkul, S. dan Krochta, J.M. (1996). Edible coating effects on postharvest quality of green bell peppers. Journal of Food Science 61(1): 176-179.

Lin, D. dan Zhao, Z. (2007). Innovations in the development and application of edible coatings for fresh and minimally processed fruits and vegetables. Comprehensive Reviews in Food Science and Food Safety 6: 60-68.

Meilgaard, M., Civille, G.V. dan Carr, B.T. (1999). Sensory Evaluation Techniques. $3^{\text {rd }}$ Edition. CRC Press, New York. Pp 416. 
Miller, W.R., Spanding, D.L. dan Risse, L.A. (1983). Decay firmness and color development of Florida bell peppers dipped in chlorine and imazalil and film wrapped. Proceedings at the Annual Meeting of Florida State Horticultural Society 96: 347-350.

Miskiyah, Widaningrum dan Winarti, C. (2010). Edible coating berbasis pati sagu dan vitamin $\mathrm{C}$ untuk meningkatkan daya simpan paprika merah (Capsicum Anum var. Athena). Jurnal Penelitian Pascapanen Pertanian 7(2):9-16.

Nielsen, S.S. (2003). Instructor Manual for Food Analysis; Answer to Study Question. $3^{\text {rd }}$ Edition. Kluwer Academic Plenum Publisher, New York. pp.154.

Olivas, G.I., Mattinson, D.S. dan Barbosa-C'anovas, G.V. (2007). Alginate coatings for Preservation of minimally processed gala apples. Postharvest Biology Technology 45: 89-96.

Robson, M.G., Nilda, F.F.S., Diego, A.B. dan Leticia, A.G. (2008).Characterization and effect of edible coatings on minimally procesed garlic quality. Carbohydrate Polymers 72: 403-409.
Santoso, B., Daniel. S. dan Rindit, P. (2004). Kajian teknologi edible coatings dari pati dan aplikasinya untuk pengemas primer lempok durian. Jurnal Teknologi dan Industri Pangan 2004(XV): 3.

Sethu, K.M., Priiya,T.N., Prabha, R.N. dan Tharanathan (1996). Post-harvest biochemical changes associated with the softening phenomenon in Capsicum annuum fruits. Phytochemistry 1996: 42(4): 961-966.

Vina, S.Z., Mugridge, A., Garcia, M.A., Ferreyra, R.M., Martino, M.N., Chavaes A.R. dan Zaritzky, N.E. (2007). Effect of polyvinylchloride film and edible strach coatings on quality aspects of refrigerated Brussels sprouts. Food Chemistry 103: 701-709.

Wojdyla, T., Poberezny, J. dan Rogozinska, I. (2008). Changes of vitamin $\mathrm{C}$ content in selected fruits and vegetables supplied for sale in the autumn-winter period. EJPAU 11(2): 11 .

Yusniwati, I., Suliansyah dan Dayati, H. (2004). Pengaruh konsentrasi nutrisi pada budidaya paprika secara hidroponik. Stigma 12(2): 171-176. 